\title{
Lysogeny in Leuconostoc oenos
}

\author{
ElKe K. Arendt, ${ }^{1 *} \dagger$ Aline Lonvaud ${ }^{2}$ and Walter P. Hammes ${ }^{1}$ \\ ${ }^{1}$ Institut für Lebensmitteltechnologie, Universität Hohenheim, Garbenstraße 25, D-7000 Stuttgart 70, Federal Republic of \\ Germany \\ ${ }^{2}$ Institut d-CEnologie, Université de Bourdeaux II, 351, Cours de la Libération, 33405 Talence Cedex, France
}

(Received 27 November 1990; revised 4 March 1991; accepted 16 April 1991)

\begin{abstract}
Thirty strains of Leuconostoc oenos were exposed to mitomycin $\mathbf{C}$ to induce lysogenic bacteriophages. Lysis curves typical for lysogenic strains were obtained with 19 strains. Indicator strains were found for 17 of these phages. Five were characterized by electron microscopy, lytic spectrum, molecular masses of the proteins, sequencing of five $\mathbf{N}$ terminal amino acids of the two major proteins and DNA analysis (restriction patterns, cross hybridization). The results revealed a very close relationship between the phages. Hybridization experiments between the DNAs of the temperate phages and the appropriate lysogenic strains revealed phage-related sequences in the DNA of the lysogenic strain.
\end{abstract}

\section{Introduction}

Malolactic fermentation in wine is performed by several species of lactic acid bacteria, of which the best adapted to the very acidic medium is Leuconostoc oenos. This organism is now used as a starter culture for malolactic fermentation in wine production. As in the dairy industry, bacteriophage infections of $L$. oenos may cause considerable economic losses (Sozzi et al., 1982: Cazelles \& Gnaegi, 1982; Henick-Kling et al., 1986). The phage problem appears not only in wine during malolactic fermentation, but also in the production of $L$. oenos starter cultures (Arendt et al., 1990). Lysogenic starter cultures are a possible source of phage. Lysogeny was reported for Lactococcus (Reiter, 1949) and Lactobacillus (Sechaud et al., 1988), but no reports about lysogeny in other lactic acid bacteria are available hitherto (Davidson et al., 1990). In this communication a detailed description of lysogeny in $L$. oenos is presented.

\section{Methods}

Bacterial strains. Thirty Leuconostoc oenos strains were examined, of which 26 were isolated in our laboratory from wines and fruit mashes. $L$. oenos strains 23,28 and BML were kindly provided by T. Sozzi, Nestlé, Orbe, Switzerland and L. oenos S1.1. was a gift from T. HenickKling, Cornell University, Geneva, NY, USA.

$\nmid$ Present address: The Department of Food Microbiology, University College Cork, Cork, Ireland.

Abbreviation: MC, mitomycin C.
Media. The propagation of strains was carried out at $30^{\circ} \mathrm{C}$ in modified MRS medium, pH 4.5 (MRSM) (Henick-Kling et al., 1986). For preparation of phage lysates, the medium was supplemented with 6.8 $\mu \mathrm{M}-\mathrm{CaCl}_{2}$. MRSM agar contained $2 \%$ agar and MRSM soft agar contained $20 \mathrm{mM}-\mathrm{CaCl}_{2}$ and $1 \%$ agar.

Bacteriophage titration and induction by mitomycin $C(M C)$. Bacteriophage titration and induction experiments with $\mathrm{MC}$ were carried out as previously described (Arendt et al., 1990). MC $\left(0.5\right.$ or $\left.1 \mu \mathrm{g} \mathrm{ml}^{-1}\right)$ was added at different stages of growth.

Screening for indicator strains. Lysates obtained after MC induction were filtered through $0.45 \mu \mathrm{m}$ filters (Millipore) and their lytic spectra were determined by studying the sensitivities of $L$. oenos strains as indicators in spot tests. These were carried out as follows: $0.5 \mathrm{ml}$ of a $48 \mathrm{~h} \mathrm{~L}$. oenos culture was added to $3.5 \mathrm{ml}$ MRSM soft agar (prewarmed to $47^{\circ} \mathrm{C}$ ) and poured on an MRSM agar plate. After $1 \mathrm{~h}, 5 \mu \mathrm{l}$ of sterile filtered lysate were dropped on the soft agar. The plates were incubated at $30{ }^{\circ} \mathrm{C}$ in an atmosphere of $10 \% \mathrm{CO}_{2}$ and $90 \% \mathrm{~N}_{2}$.

Purification of phages. The concentration and purification of the phages were carried out essentially according to Yamamoto et al. (1970). The phages were concentrated by a two-step precipitation with $5 \%$ and $10 \%$ polyethylene glycol 6000 in the presence of $1 \mathrm{M}-\mathrm{NaCl}$, and were purified by a caesium chloride step gradient overlaid with $20 \%$ sucrose (modified from Maniatis et al., 1982).

Isolation of phage DNA. The procedure of Maniatis et al. (1982) was used for DNA extraction.

Electron microscopy. The phages were negatively stained with $2 \%$ uranyl acetate and examined in a JOEL $1200 \mathrm{EX}$ transmission electron microscope at an acceleration voltage of $120 \mathrm{kV}$.

Sodium dodecylsulphate (SDS) polyacrylamide gel electrophoresis $(P A G E)$. The purified phage particles were dialysed against doubledistilled water and disintegrated by boiling for $10 \mathrm{~min}$ in an equal volume of sample buffer (Laemmli, 1970). The samples were subjected to electrophoresis on a $12 \%(\mathrm{w} / \mathrm{v})$ polyacrylamide gel at $200 \mathrm{~V}$ and 
stained with Coomassie Blue (Merck). Low Range Markers (Bio-Rad) were used as molecular mass standards.

Amino acid sequence determination. The proteins were blotted on a PVDF-membrane (Millipore) in a mini-electrophoresis chamber (Mini-Protean II Dual Slab cell, Bio-Rad) according to the supplier's recommendations. The membrane was stained with Coomassie Blue after blotting. The sequence of five $\mathrm{N}$-terminal amino acids was determined with an Applied Biosystems $471 \mathrm{~A}$ protein sequencer using a 140A Solvent Delivery System (standard program).

Restriction enzyme analysis. The phage DNA was digested with restriction enzymes (Boehringer) according to the supplier's recommendations. Fragments were separated on $0.8 \%$ agarose gels in TBE buffer (Maniatis et al., 1982), and the sizes were determined using HindIII/EcoRI digested $\lambda$-DNA as standards (Boehringer).

DNA/DNA hybridization. Restriction-enzyme-generated DNA fragments were blotted on a nylon membrane (Pall, Dreieich, Germany) by the protocol of Southern (1975) and hybridized with digoxigeninlabelled phage DNA. The procedure was carried out according to the supplier's recommendations (Boehringer).

\section{Results}

Cell lysis in Leuconostoc oenos by induction with mitomycin $C(M C)$

Dependence of cell lysis on the concentrations of $M C$. The dependence of cell lysis on MC concentration was determined for four strains of $L$. oenos. The minimum concentration for lysis was $0.3 \mu \mathrm{g} \mathrm{ml}^{-1}$. For two strains (L. oenos 32 and 37 ) $0.5 \mu \mathrm{g} \mathrm{ml}^{-1}$ was the optimum and for the other two (L. oenos 54 and 72), $1 \mu \mathrm{g} \mathrm{ml}^{-1}$. The results obtained with L. oenos 37 (Fig. 1) are depicted as typical.

Dependence on the growth phase of the culture. The dependence of cell lysis on the growth phase was studied with four L. oenos strains (L. oenos 32, 37, 54 and 72). At various points of the growth phase $\mathrm{MC}$ was added to the culture medium. In all four strains lysis was at a maximum when $\mathrm{MC}$ was added after $6 \mathrm{~h}$ of growth. The results obtained with L. oenos 37 (Fig. 2) are shown as an example.

Screening for temperate phages and indicator strains. MC $\left(0.5\right.$ or $\left.1 \mu \mathrm{g} \mathrm{ml}^{-1}\right)$ was added to strains of $L$. oenos after $6 \mathrm{~h}$ growth. It was observed that 19 strains were susceptible to lysis, 2 strains exhibited a strong growth inhibition and 9 strains were hardly affected by MC. After the MC treatment, all 30 cultures were tested for presence of phages. The same $30 \mathrm{~L}$. oenos strains were tested as possible indicator strains and for 17 out of the 19 lysis-sensitive strains, indicator strains could be found (Table 1). None of the 17 isolated temperate phages lysed the strain it was induced from. Five phages were chosen for detailed characterization.

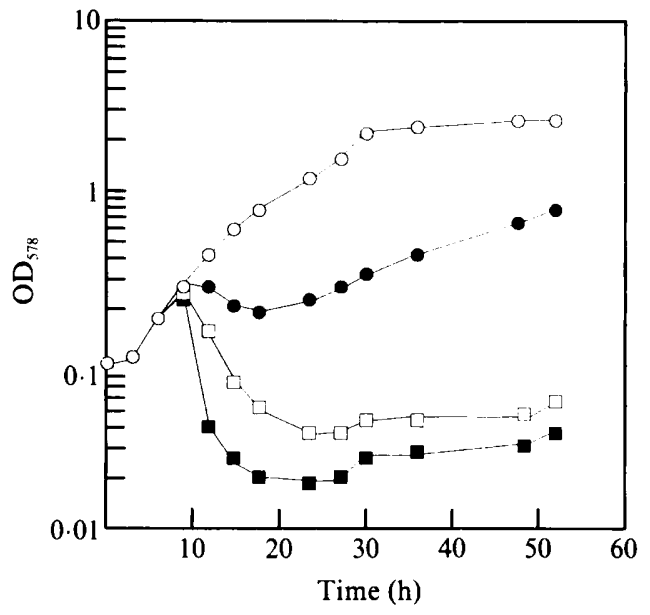

Fig. 1. Effect of mitomycin $\mathrm{C}(\mathrm{MC})$ concentration on lysis of Leuconostoc oenos 37. $\mathrm{MC}$ concentrations $\left(\mu \mathrm{g} \mathrm{ml}^{-1}\right)$ : $\mathrm{O}$, zero (control); $0,0.05: \square, 0 \cdot 1 ; \square, 0 \cdot 3$. Higher concentrations of $\mathrm{MC}$ (up to $1 \mu \mathrm{g} \mathrm{ml}^{-1}$ ) led to lysis curves identical to the curve obtained with $0.3 \mu \mathrm{g} \mathrm{ml}^{-1}$ (data not shown).

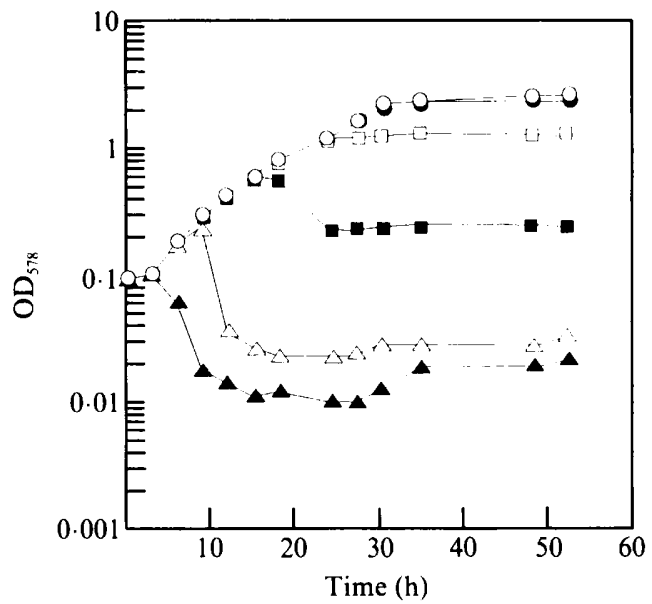

Fig. 2. Effect of growth phase on the lysis of Leuconostoc oenos 37 by mitomycin $\mathrm{C}(\mathrm{MC})$. $\mathrm{MC}$ was added to the culture medium to a final concentration of $0.5 \mu \mathrm{g} \mathrm{ml}^{-1}$ at the following times: $\bigcirc$, no $\mathrm{MC}$ added (control); $\triangle, 0 \mathrm{~h} ; \triangle, 6 \mathrm{~h} ; \square, 12 \mathrm{~h} ; \square, 18 \mathrm{~h} ; 0,24 \mathrm{~h}$.

Table 1. Effect of MC on strains of $L$. oenos

Symbols: + , lysis; - , no lysis; \pm , strong growth inhibition.

\begin{tabular}{|c|c|c|}
\hline $\begin{array}{l}\text { Strain lysed } \\
\text { with MC }\end{array}$ & $\begin{array}{l}\text { Plaque formation } \\
\text { of the lysate }\end{array}$ & Strains \\
\hline+ & + & $\begin{array}{l}\text { Lo11, Lo32, Lo33, Lo35, Lo37, Lo54, } \\
\text { Lo72, Lo107, LoAH1t7-1, } \\
\text { LoATHt7-8, LoBML, LoAH1t7-2 } \\
\text { LoS1.1, LoZ75H1t7-2, LoZt10-16 } \\
\text { LoAt5-12 and LoZt11-15 }\end{array}$ \\
\hline+ & - & Lo36 and Lo38 \\
\hline- & - & $\begin{array}{l}\text { LoAt7-6, Lo23, Lo28, Lo27, Lo42, } \\
\text { Lo } 77 \text {, LoZt6-1 1, LoAt5-9 and } \\
\text { Lo58PF }\end{array}$ \\
\hline \pm & - & LoZH1t7-5 and LoZH1t7-6 \\
\hline
\end{tabular}



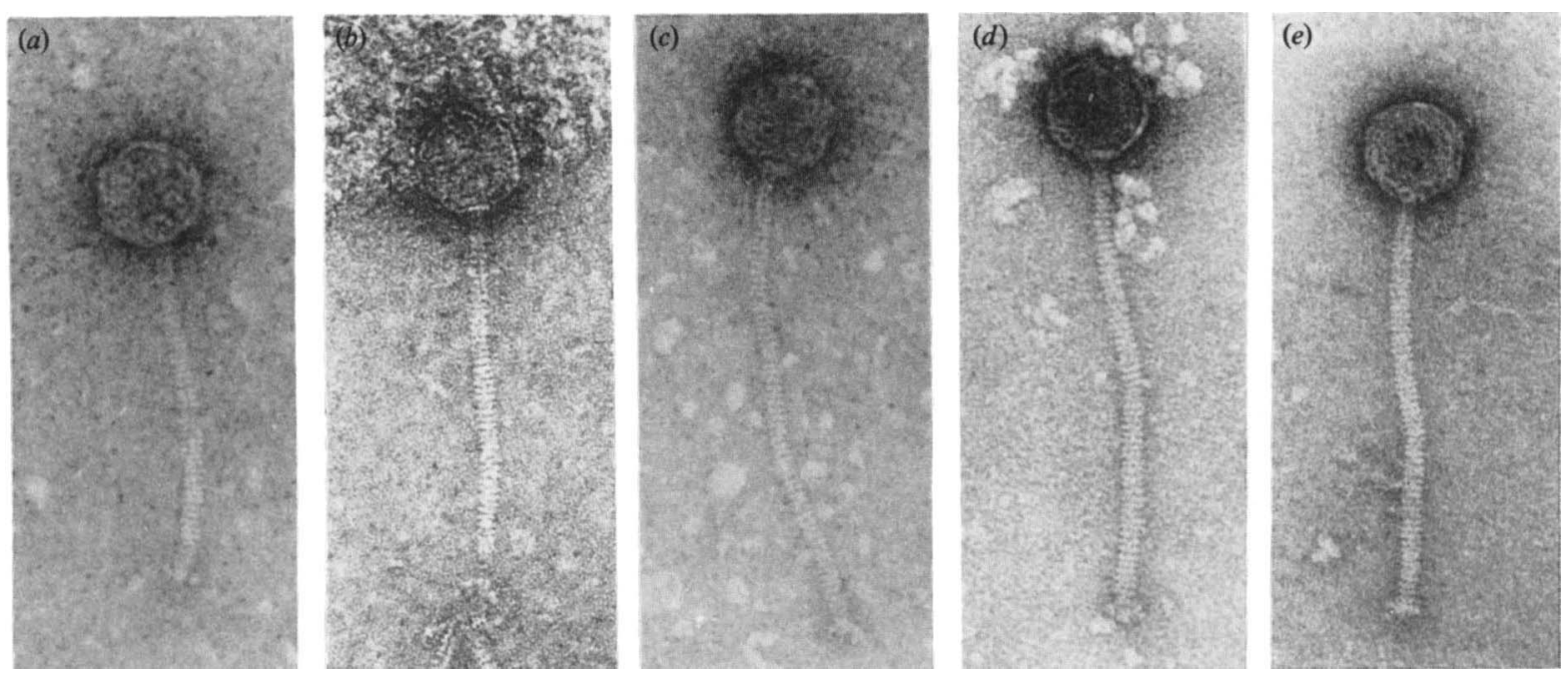

Fig. 3. Electron micrographs of bacteriophages P32 (a), P37 (b), PAt5-12 (c), PZt11-15 (d) and P54 (e).

Table 2. Dimensions $(\mathrm{nm})$ of temperate phages from L. oenos Between 10 and 20 phages were examined for each measurement.

\begin{tabular}{llllc}
\hline \hline & & \multicolumn{2}{c}{ Tail } & \\
\cline { 3 - 4 } Phage & Head & Length & Width & Base plate \\
\hline P37 & $53 \pm 2$ & $183 \pm 20$ & $11 \pm 1$ & None \\
P32 & $53 \pm 2$ & $179 \pm 15$ & $10 \pm 1$ & $20 \pm 3$ \\
P54 & $54 \pm 3$ & $221 \pm 6$ & $14 \pm 1$ & 24 \\
PAt5-12 & $54 \pm 3$ & $257 \pm 8$ & $10 \pm 1$ & $21 \pm 1$ \\
PZt11-15 & $58 \pm 3$ & $263 \pm 10$ & $14 \pm 2$ & $23 \pm 3$ \\
\hline \hline
\end{tabular}

\section{Characterization of the temperate phages}

Phage morphology. The electron micrographs of the phages P32, P37, PAt5-12, PZt11-15 and P54 (Fig. 3) show that they all have similar morphology. They are characterized by isometric heads, and differ slightly in head size, tail length and the presence or absence of a base plate (Table 2).

Lytic spectra. The host spectra of the 5 phages were determined with a set of 30 strains of $L$. oenos. Phages PZt11-15 and PAt5-12 possess the same lytic spectrum, whereas the other 3 phages differed (Table 3 ).

Protein composition. The structural proteins of the phages were analysed by SDS-PAGE (Fig. 4). The major proteins of P54 and P32 (tracks 2 and 4) were very similar, as were those of PAt5-12 and PZt11-15 (tracks 1 and 5). For P54 and P32, the minor proteins were also very similar in size. Phage P37 (track 3 ) only had one major protein similar to P54 and P32; the rest of the pattern was unique.

Sequences of five $N$-terminal amino acids of the major phage proteins. As the two major proteins of the phages

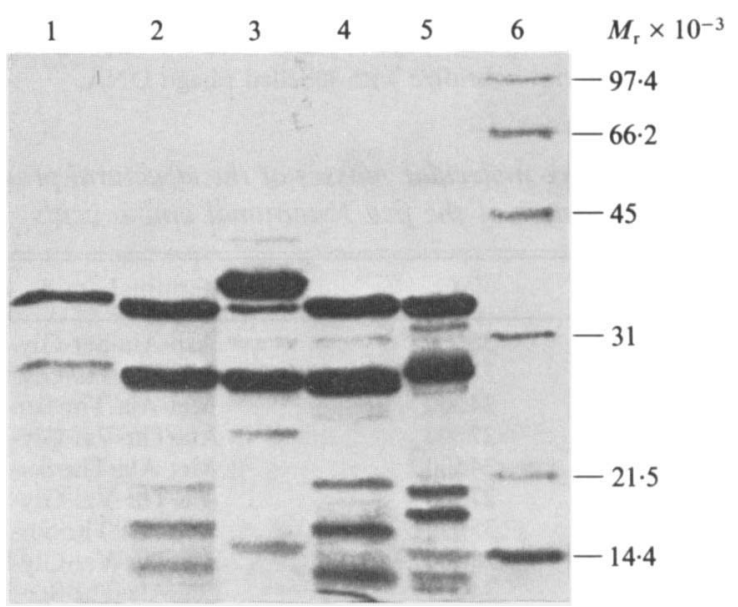

Fig. 4. SDS-PAGE of structural proteins of phages. Lanes: 1, PAt5-12; 2, P54; 3, P37; 4, P32; 5, PZtI1-15; 6, molecular mass markers.

Table 3. Lytic spectra of five L. oenos phages Symbols: + , lysis; - , no lysis.

\begin{tabular}{lccccc}
\hline \hline Strain & $\begin{array}{c}\text { Phage } \\
\text { P54 }\end{array}$ & $\begin{array}{c}\text { Phage } \\
\text { P32 }\end{array}$ & $\begin{array}{c}\text { Phage } \\
\text { P37 }\end{array}$ & $\begin{array}{c}\text { Phage } \\
\text { PAt5-12 }\end{array}$ & $\begin{array}{c}\text { Phage } \\
\text { PZt11-15 }\end{array}$ \\
\hline Lo28 & + & + & + & + & + \\
Lo23 & - & - & - & + & + \\
Lo54 & - & + & + & - & - \\
Lo32 & - & - & + & - & - \\
\hline \hline
\end{tabular}

were very similar in size, we compared the sequence of five $\mathrm{N}$-terminal amino acids (Table 4). The sequence of the smaller protein was the same for each phage. For the larger protein, phages P32 and P54 exhibited the same $\mathrm{N}$-terminal sequence as did PZt11-15 and PAt5-12. The sequence of the two groups differed only in the first amino acid. Phage P37 had a unique sequence. 


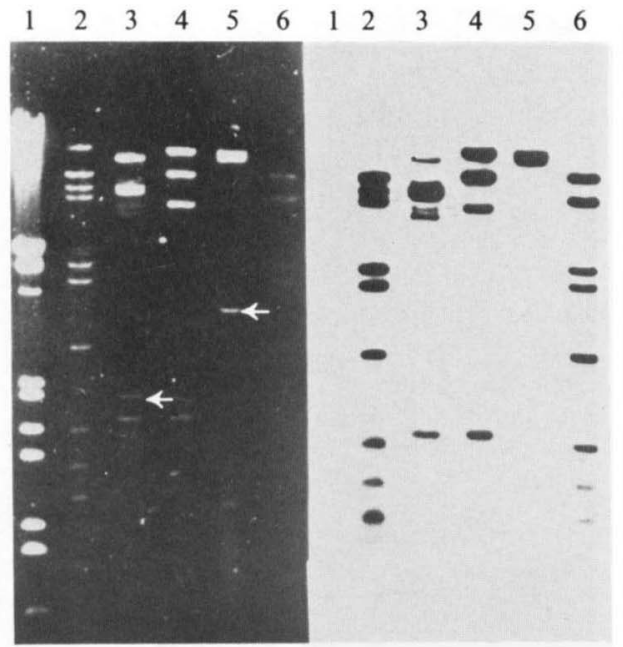

Fig. 5. Agarose gel electrophoresis of EcoRI-generated DNA fragments of phage DNAs (left) and the corresponding Southern blots hybridized with digoxigenin-labelled intact DNA of phage PAt5-12 (right). Lanes: 1, phage $\lambda$ HindIII/EcoRI; 2, phage PZt11-15; 3, phage P32; 4, phage P54; 5 , phage P37; 6, phage PAt5-12. Arrows indicate bands which did not hybridize with labelled phage DNA.

Table 4. Relative molecular masses of the structural proteins and sequences of the five $N$-terminal amino acids

\begin{tabular}{lcc}
\hline \hline Phage & $M_{\mathrm{r}}$ & N-terminal amino acids \\
\hline P37 & 36500 & Asp-Ala-Ser-Gly-Val \\
& 27500 & Ala-Thr-Val-Gly-Leu \\
P32 & 34500 & Met-Ala-Thr-Ser-Ser \\
& 27500 & Ala-Thr-Val-Gly-Leu \\
P54 & 34500 & Met-Ala-Thr-Ser-Ser \\
& 27500 & Ala-Thr-Val-Gly-Leu \\
PAt5-12 & 35000 & Leu-Ala-Thr-Ser-Ser \\
& 28500 & Ala-Thr-Val-Gly-Leu \\
PZt11-15 & 34500 & Leu-Ala-Thr-Ser-Ser \\
& 28000 & Ala-Thr-Val-Gly-Leu \\
\hline \hline
\end{tabular}

Restriction enzyme analysis. The DNAs of the phages were compared by restriction endonuclease analysis with EcoRI as shown in Fig. 5. The DNA fragment patterns

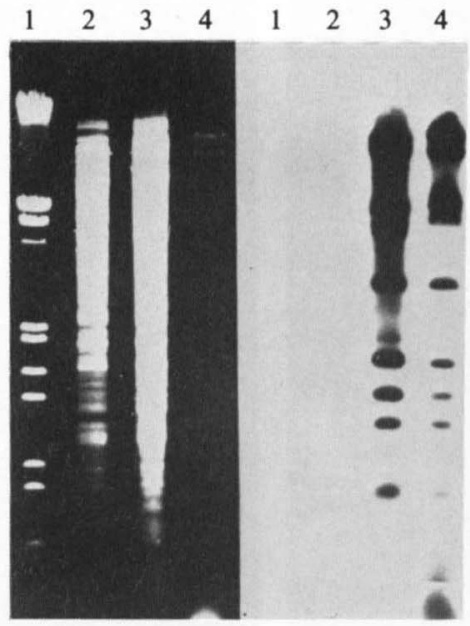

Fig. 6. Agarose gel electrophoresis of EcoRI-generated DNA fragments of phage DNAs and bacterial DNAs (left) and the corresponding Southern blots hybridized with digoxigenin-labelled intact DNA of phage PAt5-12 (right). Lanes: 1, phage $\lambda$ HindIII/EcoRI ; 2, L. oenos 28; 3, L. oenos At5-12; 4, phage PAt5-12.

of all phages were different, however phage PZt11-15 only differed by the presence of one additional fragment $(9 \cdot 4 \mathrm{~kb})$ compared to PAt5-12.

\section{DNA/DNA hybridization}

DNA samples of phages PZt11-15, P32, P54, P37 and PAt5-12 were labelled with digoxigenin and hybridized with the EcoRI generated fragments of the 5 phages after Southern blotting. In Fig. 5, an example is given with phage PAt5-12 used as a probe. The results are summarized in Table 5. Homologous DNA regions were detected in all 5 phages. In some cases they hybridized strongly, but a few fragments did not hybridize.

Sequences in chromosomal DNA homologous to the DNA of phages. To determine whether the 5 phages were of a

Table 5. DNA homologies between the phages

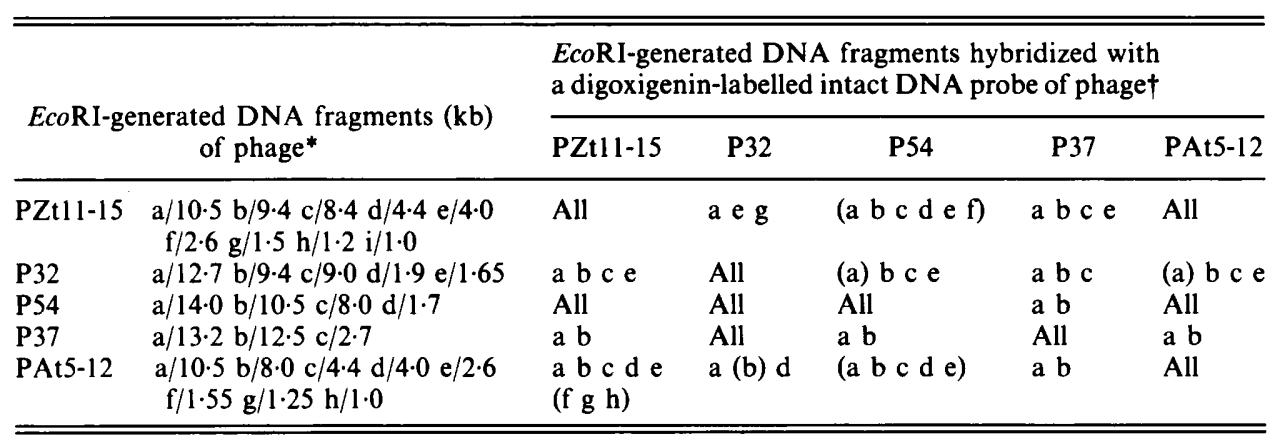

* The letters indicate the fragments in order of size, as determined by gel electrophoresis.

† Fragments in brackets indicate weak hybridization signals. 
temperate nature, phage DNA was used as a probe and hybridized with the EcoRI-digested DNA of the lysogenic strains. In all cases, homologous sequences were detected in the DNA of the lysogenic strain, but no hybridization occurred with the indicator. As an example, the results for phage PAt5-12 are illustrated in Fig. 6. Two additional bands are visible in the lysogen sample (track 3) which are absent from the phage DNA. These bands probably represent fragments emerging from the disruption of the phage attachment site.

\section{Discussion}

It has been shown that the use of lysogenic starters for industrial fermentation is a source of bacteriophage contamination (Shimizu-Kadota et al., 1983). Therefore, it is necessary to screen starter culture strains for lysogeny, especially in the dairy industry (Davidson et al., 1990). In this report the existence of lysogeny in Leuconostoc oenos has been demonstrated for the first time. Almost $60 \%$ of the 30 strains examined were lysogenic, indicating that this problem should also be taken into consideration in the production of multiple and mixed strain cultures of $L$. oenos for malolactic fermentation.

Our results show that induction of prophages carried by $L$. oenos with $\mathrm{MC}$ is strongly dependent on the $\mathrm{MC}$ concentration and the age of the culture at the time of exposure. Similar observations have also been made for Lactococcus and Lactobacillus (Yokokura et al., 1974; Park \& McKay, 1975).

Comparison of previously described phages of L.oenos had revealed that they belong to the same morphological type (Arendt et al., 1990; Cazelles \& Gnaegi, 1982; Davis et al., 1985; Henick-Kling et al., 1986; Nel et al., 1987; Sozzi et al., 1982). The temperate phages described in this work also belong to this morphological group. Our detailed examination of five temperate phages showed a very close relationship of the phages with respect to morphology, DNA homology and proteins. The analysis of the five $\mathrm{N}$-terminal amino acids of the two main phage proteins suggested that the major $M_{\mathrm{r}}=27500-28500$ protein is very similar for all 5 phages. In addition, phages P54 and P32 and phages PAt5-12 and PZt11-15 have a second major protein which is quite similar. These observations were supported by the almost identical molecular masses of the respective proteins. The similarity of the protein sequence is consistent with the observation that DNA homology exists between the 5 temperate phages. Nevertheless, all phages could be distinguished from one another by differences in morphology, DNA restriction patterns and lytic spectra.
These results suggest that temperate phages constitute a reservoir that could mutate to virulent forms and cause problems in fermentations. In particular the high percentage of lysogenic strains from isolates of wine and fruit mashes suggests that virulent phages which have been isolated from wine may be derived from prophages.

This work was supported by the Arbeitsgemeinschaft Industrieller Forschungsvereinigungen e.V. (AIF-7853). We thank Dr Mercier (Bordeaux) for the help in electron microscopy and $\mathrm{M}$. KieB for sequencing the proteins. We also thank $A$. Schroeder for technical assistance and W. Gaier for helpful discussions and critical reading of the manuscript.

\section{References}

ARendt, E. K., Neve, H. \& HAmmes, W. P. (1990). Characterization of phage isolates from a phage-carrying culture of Leuconostoc oenos $58 \mathrm{~N}$. Applied Microbiology and Biotechnology 34, 221-224.

CAZELlEs, O \& GNAEGI, F. (1982). Enquête sur l'importance pratique du problème des bactériophages dans le vin. Revue Suisse de Viticulture, Arboriculture, Horticulture 14, 267-270.

Davidson, E. D., Powell, I. B. \& Hillier, A. J. (1990). Temperate bacteriophages and lysogeny in lactic acid bacteria. FEMS Microbiology Reviews 87, 79-90.

Davis, C. R., Silveira, N. F. A. \& Fleet, G. H. (1985). Occurrence and properties of bacteriophages of Leuconostoc oenos in Australian wines. Applied and Environmental Microbiology 50, 872-876.

HeNiCK-KLING, T., LeE, T. H. \& Nicholas, D. J. D. (1986). Inhibition of bacterial growth and malolactic fermentation in wine by bacteriophage. Journal of Applied Bacteriology 61, 287-293.

LAEMMLI, U. K. (1970). Cleavage of structural proteins during the assembly of the head of bacteriophage T4. Nature, London 227, 680685 .

Maniatis, T., Fritsch, E. F. \& Sambrook, J. (1982). Molecular cloning: a laboratory manual. Cold Spring Harbor, NY: Cold Spring Harbor Laboratory.

Nel, L., Wingfield, B. D., Van Der Meer, L. J. \& Van Vuuren, H. J. J. (1987). Isolation and characterization of Leuconostoc oenos bacteriophages from wine and sugarcane. FEMS Microbiology Letters 44, 63-67.

PARK, C. \& MCKaY, L. L. (1975). Induction of prophage in lactic streptococci isolated from commercial dairy starter cultures. Journal of Milk and Food Technology 38, 594-597.

REITER, B. (1949). Lysogenic strains of lactic streptococci. Nature, London 164, 667-668.

Sechaud, L., Cluzel, P., Rousseau, M., Baumgartner, A. \& ACCOLAS, J. (1988). Bacteriophages of lactobacilli. Biochimie 70, 401410.

Shimizu-Kadota, M., Sakurai, T. \& Tsuchida, N. (1983). Prophage origin of a virulent phage appearing on fermentations of Lactobacillus casei S-1. Applied and Environmental Microbiology 45, 669-674.

SOUTHERN, E. M. (1975). Detection of specific sequences among DNA fragments separated by gelelectrophoresis. Journal of Molecular Biology 98, 503-517.

Sozzi, T., Gnaegi, F., D’Amico, N. \& Hose, H. (1982). Difficultés de fermentation malolactique du vin dues à des bacteriophages de Leuconostoc oenos. Revue Suisse de Viticulture, Arboriculture, Horticulture 14, 17-23.

Yamamoto, K. R., Alberts, B. M., Benzinger, R., Lawhorne, L. \& Treiber, G. (1970). Rapid bacteriophage sedimentation in the presence of polyethylene glycol and its application to large-scale virus purification. Virology 40, 734-744.

Yoxokura, T., Kodaira, S., Ishiwa, H. \& Sakurai, T. (1974). Lysogeny in Lactobacillus. Journal of General Microbiology 84, 277284. 